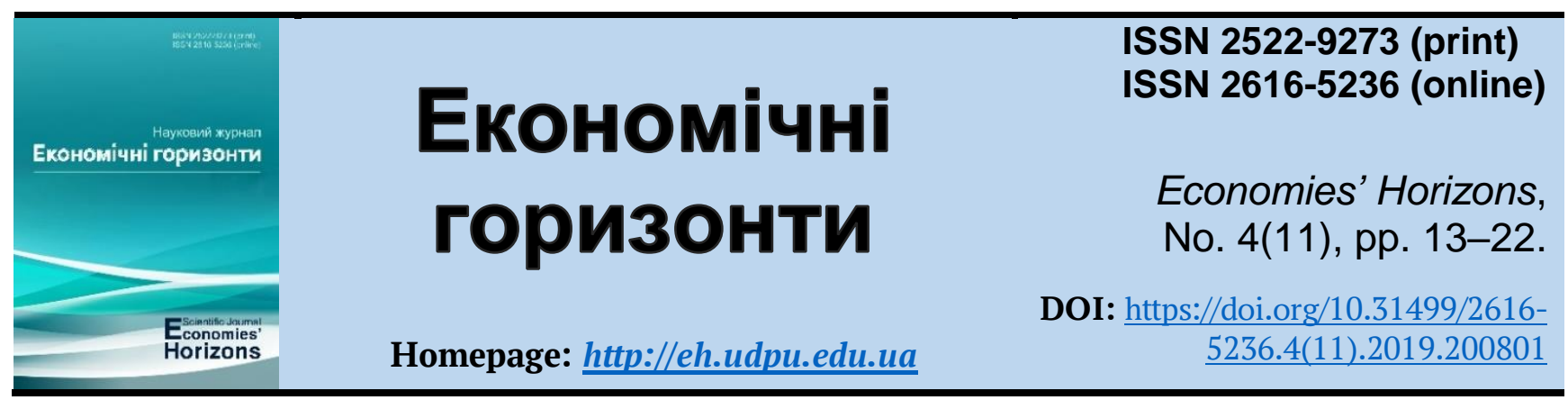

UDC 656:629.73(477):167.«712»(045)

\title{
Air transport development directions in Ukraine
}

\author{
Eleonora Yu. Tereshchenko ${ }^{1}$, Cand. Ec. Sc., Associate Professor \\ Oksana B. Shkolenko ${ }^{2}$, Cand. Ec. Sc., Associate Professor
}

Received: 20 September 2019

Accepted: 25 October 2019
Tereshchenko, E. Yu. and Shkolenko, O. B. (2019), "Air transport development directions in Ukraine", Economies' Horizons, no. 4(11), pp. 13-22, doi: https://doi.org/10.31499/2616-5236.4(11).2019.200801.

\begin{abstract}
The purpose of the research. Research of the current state of the domestic air transport market and international experience of state support of this sector, identification of opportunities and threats to its functioning in Ukraine, as well as development of directions for its future development. Methodology. A set of methods used to highlight the theoretical, legal and applied aspects of the operation of the air transport market, namely: methods of generalization, comparison, analysis, synthesis and systematic approach. Results. The role of the air transportation market in achieving the Sustainable Development Goals has been determined. The peculiarities of the development of the international air transportation market are also determined. The current state of the air transportation development is evaluated and the specifics of its state regulation in Ukraine are highlighted. The basic directions of perspective development of the air transportation market in Ukraine are substantiated. Practical meaning. Possibility of using the results of the research by the state authorities in the development of the main directions of support for the development of the domestic air transportation market under the conditions of creating a system of market differentiation into segments of air transportation; use of various forms of interaction; increase in the number of flights due to the creation of transfer passenger flows, transportation in the regions by hub airports (hubs); technical improvement; establishment of a single airport network in conjunction with efficient use of airport property; increase of investment activity of aviation enterprises. Prospects for further research. We see the prospects for further research outlined in the article in the development of mechanisms for the implementation of directions for the future development of the air transport market in Ukraine.
\end{abstract}

Keywords: air transportation, air transportation market, development of air transportation market, SWOT-analysis of the air transportation market, directions of development of air transportation market.

JEL Classification: L 93; M 21.

Number of references: 11; number of tables: 2; number of figures: 1; number of formulas: $\mathbf{0 .}$

\footnotetext{
${ }^{1}$ National Aviation University; Associate Professor at the Department of Economics and Business Technology; ORCID ID: https://orcid.org/0000-0003-2272-5224; e-mail: ellkater111@gmail.com.

${ }^{2}$ National Aviation University; Associate Professor at the Department of Economics and Business Technology; ORCID ID: https://orcid.org/0000-0003-2792-1523; e-mail: shkolenko oksana@ukr.net.
} 


\title{
Напрями розвитку ринку авіаперевезень в Україні
}

\author{
Елеонора Юріївна Терещенко ${ }^{1}$, к. е. н., доцент \\ Оксана Борисіввна Школенко ${ }^{2}$, к. е. н., доцент
}

Стаття надійшла: 20.09.2019

Стаття прийнята: 25.10.2019
Tereshchenko E. Yu., Shkolenko O. B. Air transport development directions in Ukraine. Економічні горизонти. 2019. № 4(11). C. 13-22. DOI: 10.31499/26165236.4(11).2019.200801.

Анотація. Мета статті. Дослідження сучасного стану вітчизняного ринку авіаперевезень та міжнародного досвід державної підтримки цього сектора, визначення можливостей та загроз його функціонуванню в Україні, а також розробка напрямів його перспективного розвитку. Методологія. Сукупність методів, що використовувалися для висвітлення теоретичних, правових та прикладних аспектів функціонування ринку авіаперевезень, а саме: методи узагальнення, порівняння, аналізу, синтезу та системного підходу. Результати. Визначено роль ринку авіаперевезень у досягненні Цілей сталого розвитку. Визначено особливості розвитку міжнародного ринку авіаперевезень. Здійснено оцінку сучасного стану розвитку авіаперевезень та висвітлено специфіку його державного регулювання в Україні. Обгрунтовані основні напрями перспективного розвитку ринку авіаперевезень в Україні. Практичне значення. Можливість використання результатів дослідження органами державної влади при розробці основних напрямів підтримки розвитку вітчизняного ринку авіаперевезень за умов створення системи розмежування ринку на сегменти авіаперевезень; застосування різноманітних форм взаємодії; збільшення кількості рейсів за рахунок створення трансферних пасажиропотоків, перевезень в регіонах вузловими аеропортами (хабами); технічне удосконалення; становлення єдиної аеропортової мережі в сукупності з ефективним використанням майна аеропортів; підвищення інвестиційної активності авіаційних підприємств. Перспективи подальших досліджень. Перспективи подальших досліджень окреслених у статті питань вбачаємо в розробці механізмів реалізації напрямів перспективного розвитку ринку авіаперевезень в Україні.

Ключові слова: авіаперевезення, ринок авіаперевезень, розвиток ринку авіаперевезень, SWOT-аналіз ринку авіаційних перевезень, напрями розвитку ринку авіаперевезень.

Кількість джерел: 11; кількість таблиць: 2; кількість рисунків: 1; кількість формул: 0.

\section{Introduction.}

Air transportation is a dynamic world transport industry that plays a systematic role in the economy: through close links with other industries, their development as one of the most science-intensive and innovative industries can influence the country's transition to an innovative path of development. Air transportation is also an essential element of securing Ukraine's interests in the defence and military-political spheres, an important factor in maintaining the country's sovereignty, enhancing the potential of state aviation, developing international military and technical cooperation.

\section{Literature review.}

Modern development of the theory and practice of solving the problems of functioning and development of the air transportation market has been dealt with by such domestic and foreign scientists as M. Butko and I. Sydorenko (2013), V. Heyets (2014), N. Ivanova (2015), M. Wittman (2014). However, the issues of developing promising directions for the development of the Ukrainian air transportation market

\footnotetext{
${ }^{1}$ Національний авіаційний університет; доцент кафедри економіки та бізнес-технологій; ідентифікатор ORCID: https://orcid.org/0000-0003-2272-5224; e-mail: ellkater111@gmail.com.

${ }^{2}$ Національний авіаційний університет; доцент кафедри економіки та бізнес-технологій; ідентифікатор ORCID: https://orcid.org/0000-0003-2792-1523; e-mail: shkolenko_oksana@ukr.net.
} 
remain unresolved and need further investigation.

\section{Methods.}

A set of methods used to highlight the theoretical, legal and applied aspects of the operation of the air transport market, namely: methods of generalization, comparison, analysis, synthesis and systematic approach.

\section{Research objectives.}

The main purpose of the article is to study the current state of the domestic air transport market and the international experience of state support of this sector, to identify opportunities and threats to its functioning in Ukraine, as well as to develop directions for its future development.

\section{Results and discussions.}

A turning point in the development of aviation enterprises should be considered the radical changes that took place in the country in the 1990s in economic, political and social spheres, reforms in property relations, the creation of new principles and structure of national economic management.

As a result, in the first half of the 1990s, the organization of the primary market structure of the air transport industry began, characterized by demonopolization of enterprises (which was manifested in the division of activities of airlines and airports), the abolition of state monopoly ownership, the privatization of sectoral structures with the aim of forming productive owners and developing competitive mechanisms.

The aviation industry plays a systematic role in the economy: due to its close connection with other industries, its development as one of the most science-intensive and innovative sectors of the economy is able to influence the country's transition to an innovative path of development. In addition, the aviation industry has a key influence on the formation of the engineering complex of the country. The aviation industry is also an essential element of securing Ukraine's interests in the defense and military-political spheres, an important factor in maintaining the country's sovereignty, enhancing the potential of state aviation, developing international military and technical cooperation.

Today, there is no generally accepted definition of economic development, but it is associated with economic growth based on increasing production capacity.

The role of passenger air transportation in today's economy is difficult to overestimate. It is no secret that the state of the air transportation market is directly dependent on the development of the economy and standard of living in the country. Air transport is of particular importance in a country such as Ukraine, where the economic integrity of the country depends on aviation. Research funding, well-developed infrastructure, stable external economic relations, and a domestic political balance are leading to an improvement in the well-being of citizens, resulting in increased demand for aviation services. All this, of course, contributes to the fact that the air transport market in the country is booming.

Some aspects of economic development determine how rapid population growth, structural transformation of the economy, education and health levels, international trade, globalization, the impact of epidemics, disasters, contribute to or hinder economic development.

Economic development is a phenomenon of economic science, which signifies a significant transition from one stage of the economy to another, in which in the new period not only the number of the same services and goods that have been produced before but also the production of new goods and services using modern technologies is increasing compared to the previous period (Seidman, 2005, p. 5).

K. Akamatsu distinguishes economic development from economic growth on the basis that economic development is "a broad and sustainable increase in the overall standard of living of people within the community", and such growth measures as per capita income do not necessarily correlate with improving quality of life (Akamatsu, 2012, p. 3).

Greenwood D. and Hold R. also state that since the Second World War, people have come to understand the concept of economic 
development as economic growth, namely an increase in per capita income and, if it is not present, a standard of living equivalent to that of industrialized countries (Greenwood, Daphne and Holt, 2010, p. 4).

Economic development can also be seen as a static theory that documents the state of the economy at some point in time.

Asian and European advocates for infrastructure have also argued that systematic, long-term public investment in transport, housing, education and health care is needed to ensure sustainable economic growth in developing countries.

V. Heyets under "economic development" means the regular, directional and qualitative change in the parameters of the economic subsystem of society as a result of the complexity of the structure of the system in order to reduce input resources to obtain a unit of output system, as well as: 1) economic growth should be understood as increasing volumes production of products and services in the economic system for a certain period due to a proportional increase in the factors of production used; 2) economic development should be understood as an increase in the volume of social production in the economic system by improving the productive forces and the way they are combined; 3) the development of the economy should be understood as a regular, directional and qualitative change in the parameters of the economic subsystem of society as a result of the complexity of the structure of the system in order to reduce input resources to obtain a unit of output system (Heyets, 2014, p. 221-235).

M. Butko and I. Sydorenko defines economic development as irreversible, regular changes in the technological mode of production (a method of production based on the technical and economic combination of real and personal factors of production, a complex of technical and technological relations between the real elements of productive forces in the system of technical and economic relations). However, unlike economic development, the above signs are uncharacteristic of economic growth, as growth can be interrupted by an economic downturn. Economic growth, without its inverse nature, is a component of economic development, gradually accumulating for the changes that cause the emergence of essential distortions (Butko and Sydorenko, 2013, p. 221-235).

$\mathrm{V}$. Heyets, considering that growth is an indicator of economic development, one of its most important characteristics, states that “...in modern economic theory, economic growth means not short-term ups and downs of real production relative to natural value, but long-term ones. Changes in the natural level of the real volume of production associated with the development of productive forces in the long run...”. That is, the author, characterizing "growth" as the same features as "economic development" actually identifies them. (Heyets, 2014, p. 221-235).

N. Ivanova considers the concept of "enterprise development" as an objective change only in the qualitative characteristics of the system, due to both the fundamental laws of nature (unity and struggle of opposites, the transition to quality, the development of society in a spiral and up), and the regularities of the functioning of specific systems ( aging of equipment, accumulation of experience and knowledge by employees, depletion of natural resources), under which new system properties are formed (Ivanova, 2015, p. 543-549). Thus, the process of changing the state of an object should be considered as an improvement (improvement) of its characteristics and qualitative, quantitative increase of parameters.

Researchers argue that the potential of an enterprise should be considered as an assessment of its development potential under certain stable parameters and a set of variable characteristics that describe the internal conditions. The authors have built a system for assessing the economic development of the enterprise, based on the calculations of indicators of two groups. The indicators of the first group characterize the level of achievement of the purpose of the enterprise development (improvement of business process; satisfaction of needs and expectations of consumers; 
development of internal capabilities; satisfaction of needs and interests of shareholders). The indicators of the second group are intended to assess the potential of the enterprise (indicators of production volumes; financial indicators; indicators of fixed assets and their use; indicators of material resources; indicators of human resources; social protection and use of personnel; indicators of operational efficiency; indicators of intangible assets, etc.).

In 2015, the UN approved an official document (resolution) of the UN General Assembly - "Transforming our world: A 2030 Agenda for Sustainable Development", adopted on September 25, 2015, announcing a new world-oriented action plan of sustainable development (Fig 1).

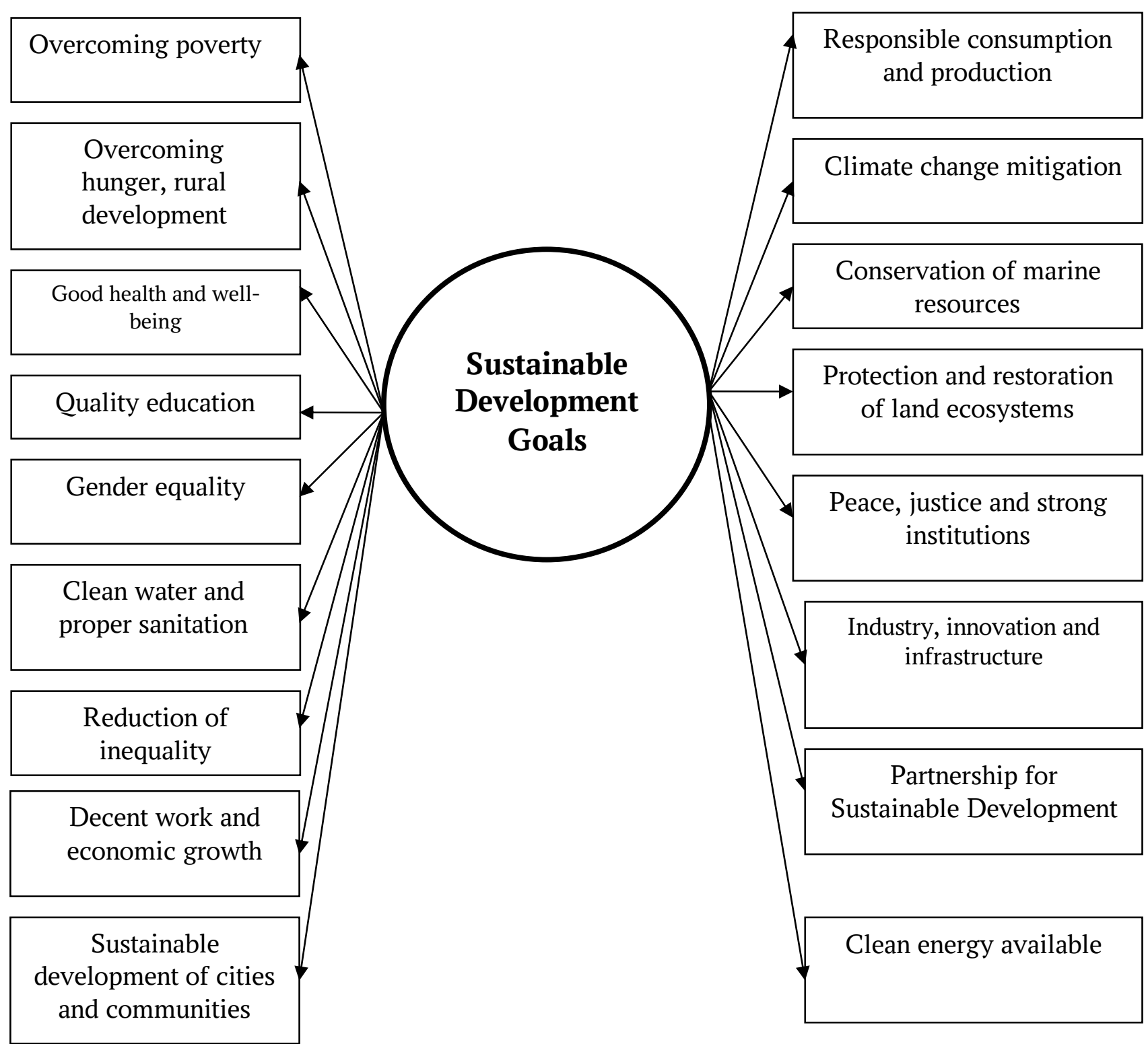

Fig. 1. Sustainable Development Goals

Source: developed by the authors.

Sustainable Development Goals (or Global Goals) are key areas of development for countries endorsed at the United Nations Sustainable Development Summit. They have replaced the Millennium Progress and Development Goals, which expired at the end of 2015. The Sustainable Development Goals have been approved for the period from 2015 to 2030 and have 17 global targets that meet 169 objectives (The Verkhovna Rada of Ukraine, 2019). 
In order to achieve the Sustainable Development Goals at the national level, Ukraine will need to implement new projects and programs that will in practice ensure environmental balance, social cohesion and macroeconomic stability.

In order to adapt the global development goals to the national specificities, national consultations were held with the participation of about 300 representatives of various government agencies, UN agencies in Ukraine, NAS of Ukraine, the public and the expert environment.

An important stage in the development of the aviation industry in countries trying to achieve the Sustainable Development Goals is the organization of a competitive air transport market, characterized by the formation of a market structure based on the smooth operation of airlines, airports, the transfer of various types of ground handling to specialized operators, as well as a clear division of market participants for profiles.

Advantages of access to aviation are to include greater access to the global air transportation network, increased investment in business and the ability to develop business competitiveness (Nolan, Ritchie and Rowcroft, 2005, pp. 28-29), increased productivity, increased employment and tourism. In addition, air transportation can serve as a characteristic of the maturity of the infrastructure and competitiveness of the state.

The excellent characteristics of air transport lie in its speed, flexibility, reliability and safety, making it often the only means of transportation for geographically remote regions. Due to the fact that the commercial operation of the aviation network is impossible due to the low traffic of vessels serving remote settlements, there is a need for financial support for route schemes.

The Ukrainian authorities should draw upon the international experience of foreign countries when developing regulatory acts regarding the subsidization of air transportation. In the EU and European Economic Area countries, the PSO (Public Service Obligation), which is also applicable to road, rail and maritime modes of transport, is a mechanism for maintaining air services in remote regions.

PSOs are systems of airlines' obligations to perform state-subsidized socially significant air services, which ensure the realization of equal rights and opportunities for residents of the country (Tuan, 2015, pp. 33-36). The PSO can be established and subsidized either by the regional or national government directly or through associated institutions. The subsidized routes in the EU, given their importance, include: routes connecting regions, capitals, regional centres of the two countries. The characteristics of such routes are low demand for passenger transportation by air, location of the airport on the periphery, the need for transportation for the economic development of the state and regions.

The grant may be awarded as a result of a tender. The tender usually provides for a minimum level of service and a maximum amount of tariffs offered by the carrier. As a rule, PSO contracts in the framework of air transport in the EU Member States are for a period of four years.

In some countries (e.g. Norway, Scotland), owners usually set a maximum fare on the PSO route; others (for example, France) require applicants to indicate their tariffs. Sweden has a system with maximum average tariffs. Italian and Portuguese PSOs connecting the islands to the mainland should offer special discounts for island residents. Other PSOs dictate that persons with disabilities, students, persons under 25 or over 70 are eligible for discounted rates.

In 1978, the Essential Air Services (EAS) program was developed, which allowed all carriers to receive a subsidy for the service of small settlements. The main purpose of the EAS is to provide transport links to remote small settlements with other regions of the state. Companies applying for a grant must provide remote area access to a hub airport, with no more than one transplant. The EAS program is run by the US Department of Transportation and funded by the federal government. The essence of the program was 
as follows: settlements, which were characterized by regular air flights in October 1978, the moment of the adoption of the Air Traffic Deregulation Act, acted as the object.

Later, restrictions were introduced to reduce the number of new settlements under the program and to reduce the overall budget for the program. The measures taken concerned the location of settlements in relation to major regional and national airports. A carrier eligible for the subsidy was determined by several factors, including fare structure, carrier reliability and intermediate and / or marketing agreements with larger carriers at a hub airport, route length, accessible airport infrastructure, volume and seasonality, and also the type of route will determine the choice of the aircraft that will benefit from the subsidy.

The Small Community Air Services Development Grant (SCASDG) has also been operating in the United States since 2002, supporting existing services for economic sustainability (Wittman, 2014).

Unlike the EAS, the subsidy is not given to carriers, but to municipalities. The frequency of flights in the summer and winter months differs, with the result that airlines introduce two types of schedules for the respective periods, with some companies not using subsidies to expand their activities.

One of the reasons is that the trips are pre-funded by Congress, for example, freight is dominated by mail-paid mail. In 1990, Congress established EAS standards such as distance and size of passenger subsidy. To be eligible for EAS, the settlement must now be located at least 70 miles from the nearest hub. The settlement may not receive more than $\$ 200$ per passenger for each flight segment, except where it is located at least 210 miles from the nearest alternative transportation center.

In 2011, the Airport and Airway Extension Act was enacted, which contains provisions prohibiting EAS distribution to settlements with annual passenger subsidies in excess of $\$ 1,000$ per passenger, regardless of distance from the nearest hub airport. The program is much more widespread in the continental United States, where approximately 120 settlements receive approximately $\$ 225$ million. in the form of subsidies for public air travel.

In Canada, the deregulation of the aviation industry was gradual, not as fast as in the US, and became official in January 1988. The deregulation concerned southern Canada, home to approximately 95 percent of the population. In a much wider part of northern Canada, a more restrictive regime continued, carriers could control market entry, tariffs and other conditions of service (Oum, Stanbury and Trethewa, 1991). Currently, according to the National Transportation Agency (CNTA), federal grants are not provided to carriers, CNTA does not control or participate in the work or provision of these social services, but in some regions grants may be provided to carriers on a competitive basis. While PSOs and EASs enter into contracts under the competitive bidding system, Canada continues to pay particular attention to supporting specific needs, such as the supply of food, medicine, mail, tools and equipment, and medical needs. Support also applies to specific travel, such as medical assistance. Canada also supports airports.

The Australian scheme is the oldest and is the result of Australia's geographical features. In Australia, deregulation began in the 1980s and affected only interstate routes (Forsyth, 1991). The Regional Aviation Access Program (RAAP) currently operates, which offers subsidies and financial support for commercially viable airports and carriers.

RAAP includes five funding components, one of which is the Remote Air Services Subsidy (RASS) Scheme, which is subject to regular weekly commuting of passengers and cargo to the outlying and isolated municipalities of Australia. The only exception is mail that is under contract with the Australian Post. Carriers are not protected by the federal government from entering other players' markets; however, the state licensing system may in some cases provide entry protection. The RASS subsidy is paid directly to the air carrier. The main features of the RAAP program are 
investments in airport infrastructure and in assisting with aeromedical flights.

In Norway, air travel to remote regions was governed by annual grant contracts, under which the government covered the local operator's shortfall for providing the service. Unlike the PSO scheme, EAS does not impede access to the market by carriers that are not covered by the subsidy program. In the event of such an airline, the US Department of Transportation notifies the incumbent carrier that a subsidy must be withdrawn, which creates incentives to minimize the size of the subsidy. The EAS limits the subsidy level to $\$ 200$ per passenger. Due to the geography, climate and long distances of the United States, Canada and Brazil to varying degrees from the air travel of passengers and cargo from remote areas. In Spain and Portugal there is a problem with the remote accessibility of the inhabitants of settlements from the islands. Each of these countries is at different stages of deregulation and development of the aviation industry. For example, the US was the first to liberalize an industry that at this stage is a mature, fully deregulated domestic market. On the contrary, Brazil maintains a degree of regulation regarding the young aviation industry in a booming environment. These countries use different approaches and intervention strategies to provide the country with air transport services. Their approaches to ensuring equal accessibility are not homogeneous: each country has different institutional structures, regulatory constraints and different entities.

Centralized and decentralized management has led to mixed results. Local airport management produces good results when settlements have a tradition of an effective management system or are interested in developing infrastructure (as in the case of the US and Portugal). Otherwise (as is the case with most municipal airports in Brazil), the decentralized approach fails. In the case of Canada, where there are two forms of governance, no evidence has been found to show that one approach works better than the other. Local government involvement is present in the US, Canada, Portugal and Spain and appears to have a positive impact on the development of air travel. In Canada and Brazil, there are several cases of public-private partnerships for the development of air services. In Finland, Sweden, Greece and Portugal, air services are regulated by national governments; within France, Italy, Spain and Germany, the PSO is managed by a regional authority. Some degree of competition is present in all countries, but its level is different between them. The most under-saturated routes are natural monopolies in every country in the sample - they are virtually uncooperative or competitive - both in the bidding process and in operation.

The current state of the air transport market in Ukraine can be represented as a SWOT analysis (Table 1). A considerable degree of regulation is at the same time related to threats and opportunities, since the liberalization of the industry, despite its advantages, has several negative consequences. For the growth of the aviation market, the state needs a clear mechanism for improving the industry. To do this, it is necessary to formulate specific options for action, including those borrowed from developed countries where the level of development of the aviation industry is high.

Summarizing the above SWOT analysis of the air transportation market in Ukraine, it is advisable to identify the main directions of its prospective development, namely:

1. Creation of hub airports. According to Ukraine's transport strategy for the period until 2030, new categories of hub airports should be created to improve the air transport market. The hub model of the organization is a modern productive trend that is popular with world leaders, a new way of globalizing industry relations. Today, this model is not developed in our country, despite the fact that Ukraine has a profitable transit potential. As a result of the formation of a unified system of hub airports on the basis of a combination of reference and regional airports, the connection of regions is ensured, competitive relations are developed and the offer is expanded. The organizational and economic mechanism for creating this system is to segment the country's airports into strategic competitive subgroups. 
Table 1. SWOT analysis of the aviation market of the Ukraine

\begin{tabular}{|l|l|}
\hline \multicolumn{1}{|c|}{ Strengths } & \multicolumn{1}{c|}{ Weaknesses } \\
\hline $\begin{array}{l}\text { An extensive network of routes. High level of } \\
\text { flight safety. }\end{array}$ & $\begin{array}{l}\text { The condition of the fleet. A large number of un- } \\
\text { profitable airlines. Weak image of companies in } \\
\text { the world market. Insufficient use of modern } \\
\text { technologies. }\end{array}$ \\
\hline \multicolumn{1}{|c|}{ Opportunities } & \multicolumn{1}{c|}{ Threats } \\
\hline $\begin{array}{l}\text { Potential for airline development. Favorable ge- } \\
\text { ographical location. Volumetric market oppor- } \\
\text { tunity for diversification of production and } \\
\text { growth of non-aviation income possibility of } \\
\text { leasing of domestic vessels. }\end{array}$ & $\begin{array}{l}\text { High prices for aviation fuel. The infrastructure } \\
\text { of the airports (especially in the regions) has de- } \\
\text { teriorated. High duties on foreign aircraft. }\end{array}$ \\
\hline
\end{tabular}

Source: developed by the authors.

Segmentation should be taken into account by airlines when preparing strategies for developing and expanding route networks. It is known that much of the world's hubs have evolved through large national carriers. Examples are Frankfurt and Munich airports developed by Lufthansa; the world-renowned London Heathrow Airport - by British Airways; in Zurich - SWISS; Amsterdam - KLM Royal Dutch Airlines; Sheremetyevo - Aeroflot Russian Airlines.

It is possible to list the following benefits for the state when creating a hub:

- the possibility of increasing the gross domestic product, creating new jobs, attracting foreign investment in the regions;

- providing links between underdeveloped areas and remote markets;

- provision of services that meet the needs of local residents (service at all destinations that are attractive to the population of the regions).

The existence of a unified strategy, including strategies of different types of air transport companies that form the hub (airlines, airports, ground handling operators), leads to a synergistic effect based on the complementarity of these elements (Table 2).

\section{Table 2. Components of the synergistic effect of creating a hub airport}

\begin{tabular}{|c|c|c|c|}
\hline Airline & Airport & $\begin{array}{l}\text { Ground han- } \\
\text { dling operators }\end{array}$ & $\begin{array}{c}\text { Passengers and cargo } \\
\text { carriers }\end{array}$ \\
\hline $\begin{array}{l}\text { The number of flights is ra- } \\
\text { tionalized with the fleet op- } \\
\text { erated (by quantity and } \\
\text { type). Increase in revenue } \\
\text { due to increased commer- } \\
\text { cial loading Reduces the } \\
\text { cost of operating multiple } \\
\text { markets due to the use of } \\
\text { more spacious aircraft. } \\
\text { Risks are reduced by keep- } \\
\text { ing the passenger in their } \\
\text { own itinerary. }\end{array}$ & $\begin{array}{l}\text { Profitability is increasing due to } \\
\text { the development of related ser- } \\
\text { vices in aviation and non-avia- } \\
\text { tion industries. Costs are re- } \\
\text { duced: - own (due to resource } \\
\text { optimization); - passenger (due } \\
\text { to reduced flight time and fuel } \\
\text { economy). The quality of ser- } \\
\text { vices is improved (including in } \\
\text { connection with the introduction } \\
\text { of competitive relations). } \\
\text { Passenger traffic is increasing }\end{array}$ & $\begin{array}{l}\text { Revenues are ris- } \\
\text { ing due to in- } \\
\text { creased demand. } \\
\text { Costs are reduced } \\
\text { through resource } \\
\text { optimization. }\end{array}$ & $\begin{array}{l}\text { Improves quality. } \\
\text { Attractive tariffs. } \\
\text { Wide range of routes. } \\
\text { Return flight return on } \\
\text { the same day. World } \\
\text { service standards. } \\
\text { Wide variety of addi- } \\
\text { tional services. }\end{array}$ \\
\hline
\end{tabular}

Source: developed by the authors.

2. Modernization of ground handling. In Ukraine, ground handling is in most cases carried out at the expense of airport forces under monopoly conditions. As a result, tariffs are uncontrollably rising and poor quality of work is observed. Annual increases in prices at some airports range from $20 \%$ to $40 \%$, while in most European countries it does not exceed $4 \%$. Thus, land-based services should be considered as a significant sector of profit and cost savings, which forms an independent competitive market, which is fixed at the legislative 
level.

It is possible to use foreign experience in this matter, as in the world on the market of ground handling services the processes of liberalization have long been implemented, associations of network operators are being formed, and outsourcing mechanisms are being developed.

3. Stimulating the creation of low-cost airlines. The analysis showed that low-cost airlines are an important factor in the development of the regional and local transportation market. The terms of tariff reductions may include: fuel economy on new aircraft types, operating single aircraft to reduce maintenance and training costs, reducing the list of services offered, creating alliances with companies, budget reductions in the form of compensation or reduction (or full cancellation) of tax payments, simplified system of routes and billing, ticket sales without agents. The concept of low-cost air carriers is popular overseas, where airline discounters are strong competitors of traditional carriers.

\section{Conclusions.}

Thus, under the development of the modern air transport market, one should understand the transition to the creation of such a mechanism of its operation, which is able to ensure a balanced relationship between segments of the air transport industry, the levels of management of industry subsystems, the market goals of business entities and the interests of the state. In the process of developing the aviation industry, it is important to address such issues as: delimiting the market into airline segments; use of various forms of interaction; increase in the number of flights due to the creation of transfer passenger flows, transportation in the regions by hub airports (hubs); technical improvement; establishment of a single airport network in conjunction with efficient use of airport property; increase of investment activity of aviation enterprises.

\section{References}

Akamatsu, K. (2012), “A historical pattern of economic growth in developing countries”, Journal of Developing Economies, no. 1, pp. 3-25.

Butko, M. P. and Sydorenko, I. V. (2013), "Evolutionary views on the modernization of different hierarchical levels of production infrastructure", Economist, no. 3, pp. 11-14.

Greenwood, D. T. and Holt, R. P. (2010), Local economic development in the 21st century: Quality of life and sustainability, Routledge, London, UK, 232 p.

Heyets, V. M. (2014), "Modernization in the system "society - state - economy", Journal of European Economics, vol. 13, issue 3, pp. 221-235.

Ivanova, N. V. (2015), "Methodological aspects of formation of prerequisites for modernization of production infrastructure", Global and National Problems of Economics, no. 6, pp. 543-549.

Nolan, J., Ritchie, P., and Rowcroft, J. (2005), "Small market air service and regional policy", Journal of Transport Economics and Policy, vol. 39, no. 3, The Economics of Cost Recovery in Transport, pp. 363378.

Oum, T. H., Stanbury, W. T. and Trethewa, M. W. (1991), "Airline deregulation in Canada and its economic effects”, Transportation Journal, vol. 30, no. 4, pp. 4-22.

Seidman, K. F. (2005), Economic development finance, SAGE Publications, London, UK, 520 p.

The Verkhovna Rada of Ukraine (2019), The Law of Ukraine "On the Fundamental Principles (Strategy) of the State Environmental Policy of Ukraine until 2030", available at: https://zakon.rada.gov.ua/laws/show/2697-19\#n14 (Accessed 29 August 2019).

Tuan, L. M. (2015), "Foreign experience and forms of government support for social significant traffic on aviation", Practical marketing, no. 2, pp. 33-36.

Wittman, M. D. (2014), "Public funding of airport incentives: the efficacy of the small community air service development grant (SCASDG) program”, MIT Small Community Air Service White Paper, no. 4, 25 p.

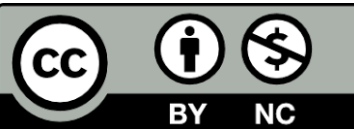

Цей твір ліцензовано на умовах Ліцензії Creative Commons «/з Зазначенням Авторства - Некомериійна 4.0 Міжнародна» (CC BY-NC 4.0).

This is an open access journal and all published articles are licensed under a Creative Commons "Attribution-NonCommercial 4.0 International" (CC BY-NC 4.0). 